\title{
PERANCANGAN MEDIA PEMBELAJARAN PAKAIAN ADAT DENGAN MACROMEDIA FLASH CS6 UNTUK TINGKAT SEKOLAH DASAR
}

\author{
John \\ Program Studi Desain Komunikasi Visual, Fakultas Seni dan Desain, \\ Universitas Potensi Utama Medan \\ john_tang01@ymail.com,
}

\begin{abstract}
ABSTRAK
Pembelajaran jarak jauh (daring) atau online pada masa sekarang ini sangat biasa dilakukan berbagai pihak sekolah dikarenakan masa pandemi virus yang melanda seluruh negara. Oleh karena itu tidak asing banyak para siswa sekolah dasar bahkan orang tua merasa jenuh dalam menghadapi pembelajaran online ini hal ini karena materi yang disampaikan guru terkadang kurang menarik minat siswa dan orangtua bingung membujuk para anaknya untuk belajar. Sebab itu penulis melakukan penelitian :Perancangan Media Pembelajaran Pakaian Adat dengan Macromedia Flash CS6 Untuk Tingkat Sekolah Dasar", perancangan ini guna meningkatkan minat para siswa dan guru dalam memberikan materi dan menerima pembelajaran secara online. Perancangan media pembelajaran ini hanya sebagai contoh bagi pengembangan media pembelajaran lainnya yang dapat diterapkan dan dikembangkan berbagai bidang mata pelajaran. Penelitian ini menggunakan teknik analisis $5 W+1 H$. Hasil perancangan berupa video interaktif yang dapat diputar berulang-ulang sehingga siswa dapat mengerti dari materi yang disampaikan. Perancangan menggunakan aplikasi Adobe Flash CS6 dan dapat dijalankan pada perangkat android.
\end{abstract}

Kata Kunci : Adobe Flash CS6, Media Pembelajaran, $5 W+1 H$

\begin{abstract}
Distance learning (online) at this time is very common in various schools due to the virus pandemic that hit the entire country. Therefore, it is not uncommon for many elementary school students and even parents to feel bored in online learning, this is because the material presented by the teacher sometimes does not attract students' interest and parents are confused about persuading their children to learn. Therefore the authors conducted research: Designing Learning Media for Traditional Clothing with Macromedia Flash CS6 for Elementary School Level ", this application is to increase the interest of students and teachers in providing material and receiving online learning. The design of instructional media is only an example for the development of other learning media that can be applied and developed in various subject areas. This research uses the $5 \mathrm{~W}+1 \mathrm{H}$ analysis technique. The design results are in the form of an interactive video that can be played repeatedly so that students can understand the material presented. The aplication uses the Adobe Flash CS6 application and can be run on android devices.
\end{abstract}

Keywords: Adobe Flash CS6, Learning Media, $5 \mathrm{~W}+1 \mathrm{H}$ 


\section{PENDAHULUAN}

Pembelajaran pada masa pandemi saat sekarang ini dituntut untuk dilakukannya pembelajaran jarak jauh (daring) yang bersifat online. Banyak terdapat kendala yang dihadapi pada proses belajar mengajar yang tidak dilakukannya tatap muka secara langsung. Hal ini menyebabkan banyak para pelajar yang enggan bahkan sampai tidak ingin melakukan kegiatan belajar walaupun bahan pembelajaran sudah disampaikan oleh para guru melalui media online.

Ada beberapa hal yang menjadi alasan bagi para pelajar mengapa enggan melakukan kegiatan belajar online tersebut, seperti :

- Beban sekolah yang terlalu banyak

- Materi yang membosankan

- Kurang mengerti materi pembelajaran

- Orang tua kurang mengerti untuk membantu pembelajaran

- Bosan

Penulis mengevaluasi beberapa alasan yang sangat menarik untuk dijadikan penelitian yakni untuk menarik minat belajar anak khususnya tingkat sekolah dasar. Mengapa penulis memilih sekolah dasar dikarenakan pada tingkat ini otak dari siswa sekolah dasar (SD) masih sangat rentan dalam berkembang sehingga perlu diperhatikan secara intens dalam tumbuh kembang otak anak tersebut. Melalui beberapa alasan tersebut penulis ingin merancang sebuah media pembelajaran yang sederhana namun menarik bagi anak-anak setingkat sekolah dasar. Pada apenelitian ini penulis hanya merancang satu contoh perancangan media pembelajaran yakni tentang pakain adat dari beberapa daerah dengan menggunakan aplikasi Adobe Flash CS6. media pembelakjaran ini juga bisa dikembangkan untuk materi pembelajaran lainnya.

\section{I.1. Media Pembelajar}

Nunu Mahnun (2012) menyebutkan bahwa "media" berasal dari bahasa Latin "medium" yang berarti "perantara" atau "pengantar".Lebih lanjut, media merupakan sarana penyalur pesan atau informasibelajar yang hendak disampaikan oleh sumber pesan kepada sasaran atau penerima pesan tersebut, sedangkan Adam dan Taufik Syastra, 2015 menyatakan media pembelajaran merupakan segala sesuatu baik berupa fisik ataupun teknis dalam tahap pembelajaran yang bisa membantu guru dalam mempermudah dalam penyampaian materi pelajaran kepada para siswa sehingga mempermudah dalam pencapaian tujuan pembelajaran yang telah dirancang. (Talizaro Tafonao, $2018: 104-105$ )

Melalui defenisi di atas penulis membuat kesimpulan mengenai defenisi dari media pembelajaran, yakni sesuatu perantara baik dalam bentuk fisik atau teknis yang dapat membatu pengajar dalam menyampaikan materi belajar dengan menarik dan mudah dimengerti oleh peserta didik sehingga apa yang disampaikan dapat tersalurkan dengan baik kepada para siswa atau peserta didik. 


\section{I.2. Fungsi dan Peranan Media Pembelajaran}

Kemp dan Dayton (1985: 28), menyatakan media pembelajaran dapat memenuhi tiga fungsi utama jika media itu digunakan kepada individu, kelompok, atau komunitas pendengar dengan jumlah yang besar, yakni

(1) memotivasi minat atau perbuatan,

(2) memberikan informasi, dan

(3) memberi perintah atau arahan. (dikutip https://telelearning.weebly.com/blog/fungsidan-peran-media-pembelajaran 19 Februari 2020)

Peranan Media pembelajaran dalam membantu tenaga pengajar atau guru dalam pembelajaran daring atau online menurut Kemp dan Dayton (1985; 3-4) walaupun tanpa disadari bahwa banyak kelebihan dalam penggunaan media pembelajaran, respon dan integrasi dalam pembelajaran masih terlihat lambat. Mereka meneliti dan mengungkapkan beberapa hasil penelitian yang menunjukkan kelebihan dari penggunaan media sebagai integral proses belajar mengajar di kelas atau sebagai cara pemberian materi belajar secara langsung dapat dilihat sebagai berikut:

1.Proses penyampaian pelajaran menjadi lebih baku. Hal ini agar setiap pelajar yang menerima materi pembelajaran melalui media menerima informasi yang sama.

2.Proses belajar bisa lebih menarik. Media pembelajaran yang diberikan dapat diasosikan untuk menarik perhatian pelajar agar lebih fokus dan memperhatikan materi pembelajaran.

3.Pembelajaran yang dilakukan para pelajar lebih interaktif dengan feed back/umpan balik yang diberikan pelajar kepada guru.

4. Waktu yang digunakan dalam pembelajran cenderung lebih singkat hal ini dikarenakan media membutuhkan waktu yang lebih singkat dalam menyampaikan pesanpesan/informasi kepada para pelajar.

5.kualitas hasil belajar dapat ditingkatkan dengan menampilkan pesan materi dan gambar yang menarik serta isi dari media pembelajaran berupa elemen-elemen pengetahuan dengan cara yang baik, spesifik dan jelas.

6.Materi pembelajaran dapat diberikan kapanpun dan dimanapun kepada pelajar terutama jika diberikan untuk pengguna individu.

7.Sikap positif pelajar terhadap materi pembelajaran yang mereka terima dapat leboh ditingkatkan.

8.Peranan guru dapat berubah ke hal yang lebih positif serta lebih mengembangkan skill teknologi yang semakin berkembang pada saat ini. (dikutip https://telelearning.weebly.com/blog/fungsi-dan-peran-media-pembelajaran 19 Februari 2020)

Media membuat pembelajaran yang awalnya membosankan bagi siswa menjadi sesuatu yang manarik, sehingga minat siswa akan meningkat dalam belajar. Hal ini dikarenakan siswa akan terus menunggu hal baru apalagi yang akan ditampilkan para guru ke mereka sehingga membuat mereka penasaran dalam hal belajar.

Peranan media juga dapat menjadi motivasi tersendiri bagi para guru untuk lebih meningkatkan skill dalam memberikan presentasi pengajaran kepada para siswanya. Bukan sesuatu yang tidak mungkin para guru juga melakukan sesuatu yang berbeda dalam 
memberikan materi pembelajaran yang menarik perhatian para siswanya jika perlu dilakukan pertemuan online dengan para siswa dan memberikan sedikit hiburan dalam pembelajaran yang dilakukan misal belajar sambil bermain game, dan lain sebagainya.

\section{I.3. Adobe Flash CS 6}

Adobe Flash adalah salah satu aplikasi pengolahan animasi sederhana, Adobe Flash CS6 merupakan aplikasi yang dikeluarkan oleh perusahaan pemrograman ADOBE, yang mana mereka juga mengeluarkan beberapa aplikasi pemrograman dan aplikasi editor yang lain seperti: Dreamweaver,Photoshop, After Effect, dan lain-lain. Adobe Flash CS6. Berikut tampilan awal Aobe Flash CS6

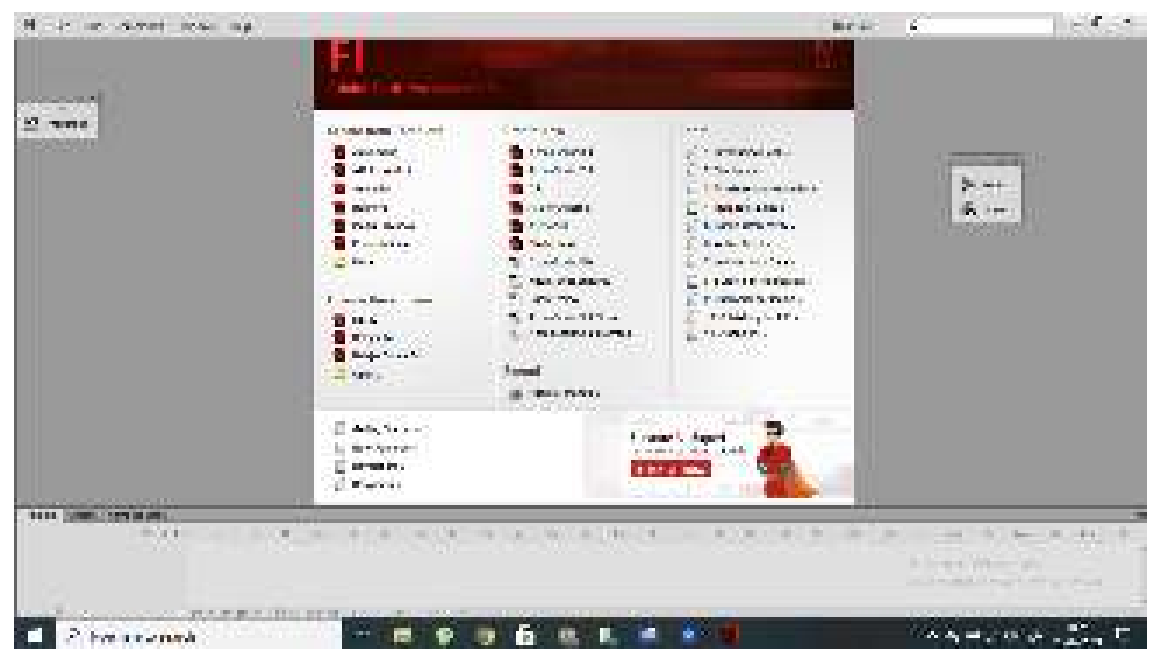

Gambar 1. Adobe Flash CS 6

\section{STUDI LITERATUR}

\section{II.1. Peranan Media Pembelajaran Dalam Meningkatkan Minat Belajar Mahasiswa}

Penelitian dari T. Tafonao tahun 2018 dengan judul "Peranan Media Pembelajaran Dalam Meningkatkan Minat Belajar Mahasiswa", di dalam tulisannya Tafonao membahas mengenai perkembangan teknologi yang semakin canggih. Melalui perkembangan tersebut diharapkan bagi para dosen/guru serta tenaga pengajar lainnya untuk dapat memanfaatkan kemajuan teknologi tersebut. Hal tersebut bertujuan untuk menggunakan kemajuan teknologi untuk dalam proses belajjar mengajar sehingga minat dari peserta didik baik siswa ataupun mahasiswa nantinya meningkat dalam memahami dan mengikuti pelajaran.

\section{II.2. Pengembangan Multimedia Pembelajaran Bahasa Indonesia Bernilai Pendidikan} Karakter Untuk Siswa Kelas V SD

Penelitian dari Hasnul Fikri dan Ade Sri Madona pada tahun 2014 yang berjudul " Pengembangan Multimedia Pembelajaran Bahasa Indonesia Bernilai Pendidikan Karakter 
Untuk Siswa Kelas V SD" membahas mengenai bagaimana tingkat hasil uji validasi pendidikan karakter pada siswa kelas V SD dengan diterapkannya multimedia sebagai media pembelajaran yang baru. Penelitian ini juga berhubungan dengan judul buku yang mereka karang dengan judul " Pengembangan Media Pembelajaran Berbasis Multimedia Interaktif"

\section{II.3. Media Pembelajaran Inovatif}

Buku yang sangat menarik untuk dijadikan bahan referensi penelitian serta acuan untuk membuat sebuah media pembelajaran yang manarik yang dikarang oleh Dr. Nurdyansyah, S.Pd., M.Pd. pada tahun 2019 yang membahas mengenai bagaimana sebuah media pembelajaran yang dirancang dan didesain sehingga dapat menarik minat dari peserta didik dan dapat mewakili dari hal-hal yang ingin disampaikan guru/dosen/ tenaga pengajar. Media pembelajaran yang menarik bukan hanya bagus dari segi visual namun juga kualitas dari isi atau konten yang ingin disampaikan sehingga tetap menjaga kualitas belajar dari peserta didik.

\section{III.PEMBAHASAN}

Perancangan media pembelajaran ini hanya sebagai contoh atau acuan untuk membangun media pembelajaran yang lainnya. Konsep dari media pembelajaran ini adalah multimedia yang menitiberatkan kepada visual serta isi atau konten yang ingin disampaikan

\section{III.1. Interface atau tampilan}

Menurut Akinari, 2012 interface adalah salah satu platform yang disediakan sistem operasi sebagai sarana interaksi antara user dengan operating system. Interface merupakan komponen sistem operasi yang langsung berhubungan dengan user. Terdapat dua jenis antarmuka, yaitu CLI (Command Line Interface) dan GUI (Graphical User Interface) (Ikhsan dan Hendra Kurniawan, 2015:14)

Interface merupakan hal yang penting dalam multimedia perancangan media pembelajaran karena biasanya para siswa terutama siswa SD akan merasa tertarik dengan visualisasi dan tampilan yang menarik. Melalui interface yang menarik sudah merupakan langkah awal untuk menarik minat belajar dari para siswa SD tersebut. Berikut tampilan interface yang dirancang dalam Media Pembelajaran yang penulis kerjakan 


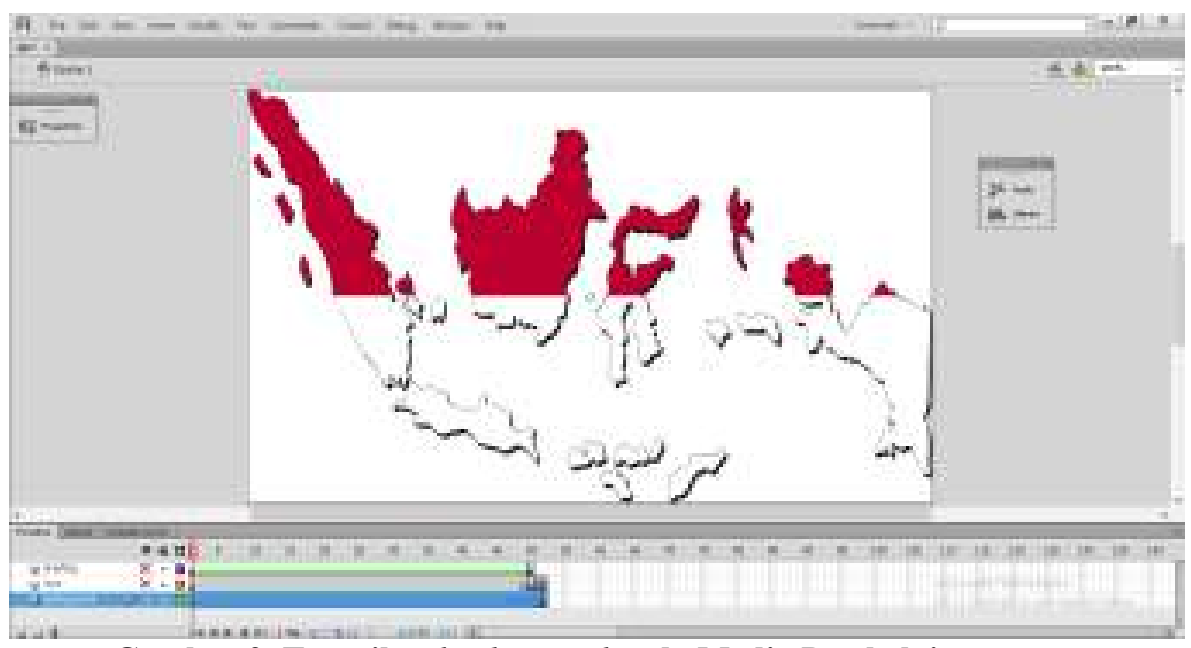

Gambar 2. Tampilan background pada Media Pembelajaran Desain : John, 2020

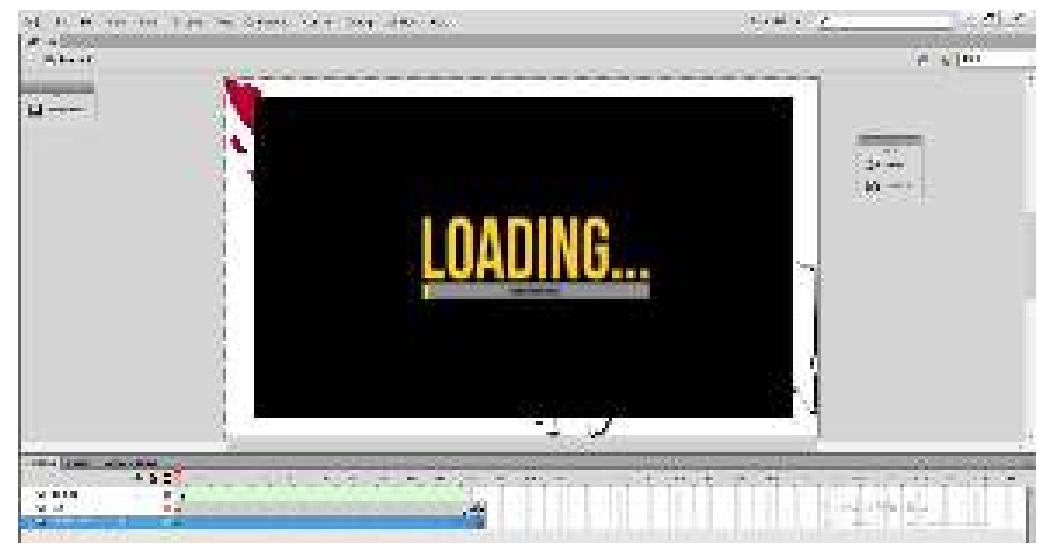

Gambar 3. Tampilan proses loading pada Media Pembelajaran Desain : John, 2020

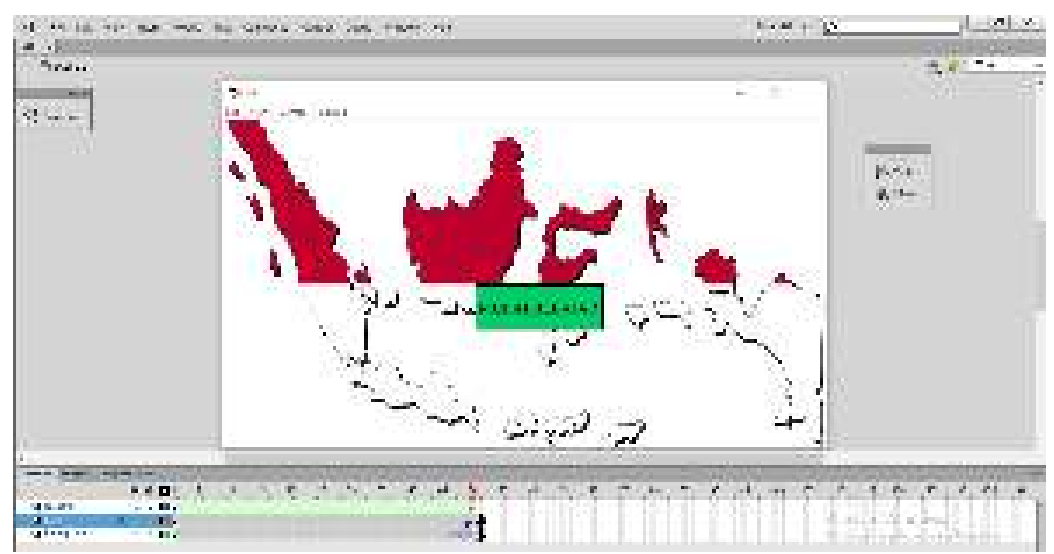

Gambar 4. Tampilan button untuk memulai pada Media Pembelajaran Desain : John, 2020

Pada tampilan awal sampai tampilan ketiga merupakan tampilan awal dari media pembelajaran ini. Pada media pembelajaran ini penulis juga menyisipkan sedikit instrumen musik ke dalam media pembelajaran agar tidak terlalu membosankan sehingga selain tampilan menarik kita juga dapat menyisipkan sedikit instrumen musik. 


\section{III.2. Isi Konten Media Pembelajaran}

Konten adalah informasi yang tersedia melalui media digital atau media elektronik. Konten bisa berbentuk teks, citra, grafis, video, audio, dokumen, laporan-laporan, dan sebagainya. Dengan kata lain, konten adalah segala sesuatu hal yang bisa diolah dalam format elektronik (Simarmata, 2011). Menurut Cambridge Dictionary, defenisi konten adalah "artikel atau bagian yang terdapat pada majalah atau buku" (the articles or parts contained in a magazine or book), dalam Business Dictionary, konten memiliki pengertian:

1. Teks dari dokumen atau publikasi yang bentuk apapun. Konten merupakan informasi yang dapat dikomunikasikan:

2. Esensi dari pesan yang dikomunikasikan, sebagaimana dipahami atau diterima oleh pendengar/audience yang dituju.

3. Lem 'yang membuat situs web' lengket 'membuat penikmat/pendengar/audience kembali, dan membuat mereka tidak pergi ke tempat lain. (Mahmudah dan Rahayu, 2020:4)

Konten dengan kata lain isi dari multimedia yang ditampilkan juga merupakan hal vital dalam perancangan media pembelajaran, hal ini karena apa yang ingin disampaikan oleh siperancanag sepenuhnya akan tampil di bagian ini. Isi konten yang menarik akan membangkitkan minat belajar dari para siswa SD dan tentunya mereka juga akan terus menanti media pembelajaran selanjutnya yang akan disajikan oleh guru mereka. Berikut tampilan isi konten media pembelajaran mengenai pakaian adat yang dirancang

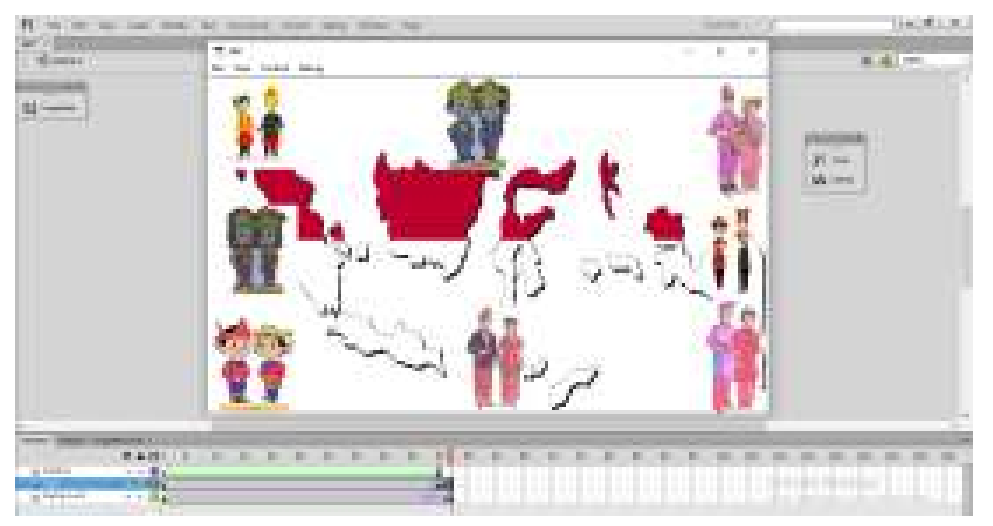

Gambar 5. Tampilan isi konten setelah menekan button mulai pada Media Pembelajaran Desain : John, 2020

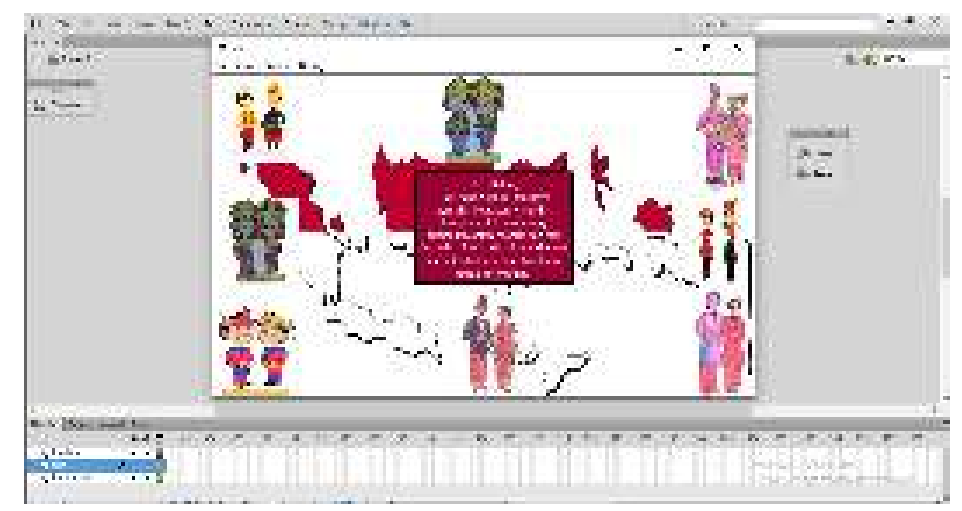

Gambar 6. Munculnya pengetahuan dari setiap gambar yang ditekan Desain : John, 2020 
Pada bagian isi konten jika kita menekan salah satu gambar pakain adat yang terdapat di media pembelajaran tersebut maka akan mengeluarkan informasi mengenai pakaian adat tersebut seperti pada gambar 5. Untuk keluar dari program cukup tekan tombol close yang di sudut kanan atas.

\section{III.3. Perintah-perintah yang digunakan dalam Adobe Flash CS6 (ActionScript)}

ActionScript adalah bahasa pemrograman yang dibuat berdasarkan ECMAScript, yang digunakan dalam pengembangan situs web dan perangkat lunak menggunakan platform Adobe Flash Player. ActionScript juga dipakai pada beberapa aplikasi basis data, seperti Alpha Five. Pada perancangan ini penulis menggunakan perintah-perintah yang sederhana sehingga untuk guru-guru SD sangat mudah untuk mengikutinya (dikutip dari https://id.wikipedia.org/wiki/ActionScript 19 Februari 2020). Berikut tampilan ActionScript yang digunakan

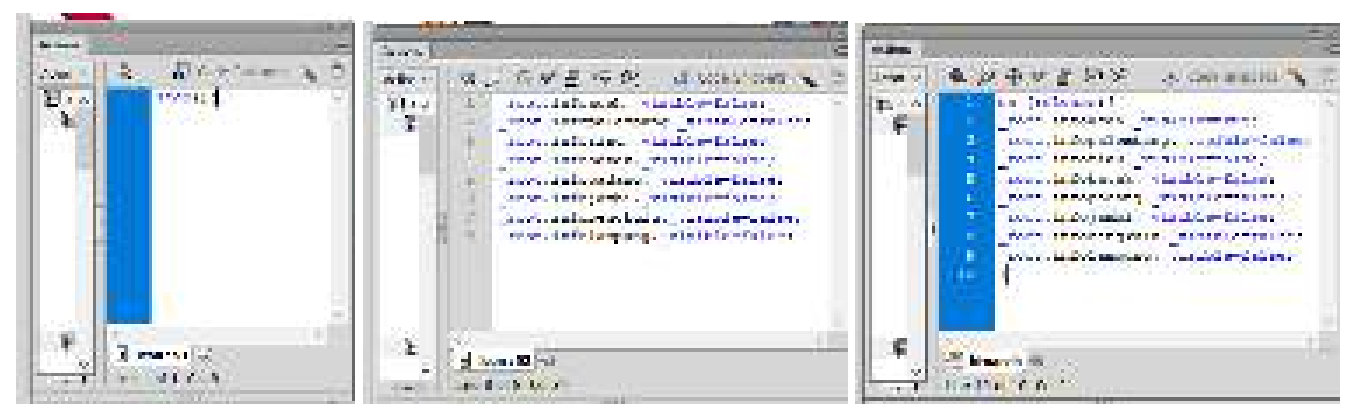

Gambar 6. Beberapa contoh ActionScript yang digunakan dalam perancangan Media Pembelajaran Sumber: John, 2020

\section{III.4. Analisis Data}

\section{III.4.1. Analisis Data $5 W+1 H$}

Sebelum melakukan perancangan media pembelajaran ini penulis melakukan analisis data dengan melakukan observasi terhadap beberapa anak-anak SD yang penulis jumpai mengenai masalah dari kurangnya minat pembelajaran daring dan online yang dilakukan oleh guru terhadap peserta didiknya. Oleh karen itu, penulis mencoba menganalisis dengan menggunakan teknik analisis data $5 \mathrm{~W}+1 \mathrm{H}$

- What, Apa yang menjadi alasan kurangnya minat belajar dari para siswa SD terhadap pembelajaran daring dan online

- Who, Siapa saja yang memberikan media pembelajaran dan siapa yang menerima media pembelajaran

- Why, Mengapa perlu merancang media pembelajaran yang menarik

- Where, Dimana media pembelajaran ini dapt digunakan

- When, Kapan media pembelajaran mulai dapat digunakan 
- How, Bagaimana cara agar para tenaga pendidik dapat merancanag media pembelajaran yang menarik

Melalui beberapa analisis yang dipaparkan di atas maka penulis menyimpulkan dalam perancangan media pembelajaran ini yang menjadi alasan kurangnya minat belajar dari para siswa karena bosan dan terkadang kurang paham dan kurang menarik dari materi yang diberikan oleh guru secara online. Para guru yang hendaknya memberikan materi-materi pembelajaran menggunakan multimedia interaktif yang menarik kepada para siswa SD.

Media pembelajaran yang menarik perlu dirancang dan diberikan kepada para siswa SD agar dapat memancing minat belajar para siswa SD selama masa pandemi. Media pembelajaran yang dirancang dapat diberikan di mana saja dan diberikan kapan saja karena bisa menggunakan aplikasi yang terdapat di android dengan memasang perangkat yang tersedia di google playstore yang bernama swf player. Hal yang harus dilakukan pihak sekolah untuk para guru agarterampil dalam merancang media pembelajaran yang menarik adalah dengan sering mengadakan workshop bagi para guru.

\section{III.3.2. Sasaran Audience}

a. Geografis, berdasarkan posisi geografis sasaran dari perancangan media pembelajaran ini adalah para siswa SD kota Medan dan sekitarnya.

b. Demografis, secara demografis sasaran dari perancangan ini yakni pria dan wanita khususnya untuk siswa-siswa SD.

c. Psikografis, secara psikografis sasaran dari perancangan ini yakni para siswa SD yang terlalu jenuh menghadapi pembelajaran daring dan online selama pandemi

\section{III.4. Tahap Perancangan dan Penggrafisan}

Perancangan yang dilakukan melalui Adobe Flash CS6 karena aplikasi ini sangat mudah digunakan untuk para guru untuk membuat tampilan yang menarik dalam menyampaikan materi kepada para siswa SD. Selain itu hasil perancangan juga tidak terlalu besar dan mudah untuk diunduh oleh para orang tua dan siswa.

Hasil rancangan dapat dengan mudah dapat disebar dan dibuka melalui android, karena hampir seluruh pembelajaran daring dan online menggunakan android. Media pembelajaran dapat dibuka atau dilihat kapan saja dan dimana saja dengan tetap memperhatikan materi pembelajaran yang diberikan.

\section{IV.PENUTUP}

Berdasarkan hasil penelitian dengan judul "Perancangan Media Pembelajaran Pakaian Adat Dengan Macromedia Flash Cs6 Untuk Tingkat Sekolah Dasar" dapat ditarik kesimpulan bahwa dengan merancang media pembelajaran yang menarik merupakan sesuatu yang baru bagi para siswa sehingga bisa menarik perhatian dan meningkatkan kemauan belajar dari para siswa SD.

Meningkatkan kemampuan para guru dalam memberikan materi pembelajaran sehingga dapat diaplikasikan pada para siswa nantinya jika proses pembelajaran tatap 
muka kembali dilaksanakan sehingga menambah minat belajar dari para siswa di dalam kelas. Para siswa juga dapat lebih fokus dalam menerima materi yang disampaikan oleh guru.

\section{DAFTAR PUSTAKA}

[1] Fakultas Keguruan dan Ilmu Pendidikan Universitas Bung Hatta. 2017. Pengembangan Multimedia Pembelajaran Bahasa Indonesia Bernilai Pendidikan Karakter Untuk Siswa Kelas V SD. JURNAL PUITIKA Vol 13, No. 2, 111-140.

[2] Ilmu Komunikasi Mercu Buana. 2020. "Pengelolaan Konten Media Sosial Korporat pada Instagram Sebuah Pusat Perbelanjaan”. JURNAL KOMUNIKASI NUSANTARA Vol 2 No.1, 1-9.

[3] Nurdyansyah. (2019). Media Pembelajaran Inovatif . Sidoarjo: UMSIDA Press.

[4] Pendidikan Agama Kristen STT KADESI Yogyakarta. 2018. "Peranan Media Pembelajaran Dalam Meningkatkan Minat Belajar Mahasiswa". JURNAL KOMUNIKASI PENDIDIKAN Vol 2 No.2, 103-114.

[5] Sistem Komputer STMIK Jaya Nusa Padang. 2015. "Implementasi Sistem Kendali Cahaya dan Sirkulasi Udara Ruangan dengan Memanfaatkan PC dan Mikrokontroler ATMEGA8”. JURNAL TEKNOIF Vol 3 No.1, 12-19.

[6] Sarwono, Jonathan dan Hary Lubis. (2007). Metode Riset untuk Desain Komunikasi Visual. Yogyakarta : Andi Offset.

[7] https://telelearning.weebly.com/blog/fungsi-dan-peran-media-pembelajaran (dikutip 19 Februari 2020)

[8] https://id.wikipedia.org/wiki/ActionScript (dikutip 19 Februari 2020) 